\title{
Analysis of energy efficiency of photovoltaic installation in central Poland
}

\author{
Mariusz Sarniak ${ }^{1, *}$ \\ ${ }^{1}$ Warsaw University of Technology, Faculty of Civil Engineering, Mechanics and Petrochemistry, \\ Institute of Mechanical Engineering, Łukasiewicza 17, 09-400 Płock, Poland
}

\begin{abstract}
The paper analyzes the electricity generation from photovoltaic micro-installation, which was not subjected to any maintenance operations such as cleaning or periodic change of the PV panel tilt angle, recorded in the years: 2015-2017. The PV micro-installation presented is a system called On-Grid, i.e. it is connected to a low voltage power network, and the PV generator is built from the two most commonly used types of PV modules: from mono- and polycrystalline silicon. Data sets for relative energy yields combined and broken down into PV generator manufacturing technologies were analyzed. The results of the measurements were also divided into percentage amounts of generated energy in two time intervals: "summer" months from April to September (on average over 80\% of generated electricity) and others recognized as "winter". This division was also made for two technologies of making a PV generator.
\end{abstract}

\section{Introduction}

The development of photovoltaics in Poland is a derivative of the country's energy policy. Under the Directive of the European Parliament 2009/28/EC, Poland is obliged to achieve a minimum 15\% share of energy from renewable sources in final gross energy consumption in 2020. The implementation plan for achieving this goal is the National Action Plan (NAP) in the field of energy from renewable sources. It assumes that the share of energy from renewable sources in the final energy consumption will be higher than the set minimum and will amount to $15.85 \%$. Currently (until the end of 2017), 29197 solar systems with a total capacity of 281.4 MW have been installed in Poland. This number consists of 589 units of systems licensed by the Energy Regulatory Office (URE) with a total capacity of $107.7 \mathrm{MW}$ and 28608 units of prosumer systems with a total capacity of 173.7 MW [1].

Peak power values, which are reported by the manufacturers of solar modules, are very rarely obtained in practice in Poland (Central and Eastern Europe). STC (Standard Test Conditions) in which new modules are tested in this location do not actually occur. Poland lies in the zone of large differences in the size of solar radiation in the winter and summer months. The genesis of the paper is the search for optimal solutions based on the

\footnotetext{
* Corresponding author: mariusz.sarniak@pw.edu.pl
} 
observation of energy yields in PV systems that already exist in a given location. In the paper, the PV system connected to the utility network was tested.

At present, virtually all manufacturers of inverters used in PV systems provide adequate additional equipment that allows monitoring of their operation. PV system monitoring is not only an effective gadget, but above all, continuous registration of basic operating parameters, enabling analysis and detection of all kinds of irregularities. The preview of data from monitoring from mobile devices may also be a kind of security element protecting the external elements of the PV system against theft and vandalism.

\section{Test stand description}

The test stand is the demonstrative mini PV system, located in Płock (GPS coordinates: $52.546713 \mathrm{~N}, 19.706945 \mathrm{E}$ ), on the flat roof of a three-storey University building. The PV generator was built from modules of the two most popular types of mono- and polycrystalline silicon (Fig. 1). The PV modules are mounted in the azimuthal deviated by $27^{\circ}$ from the direction of the South to the West and inclined at an angle of $45^{\circ}$ to the horizontal.

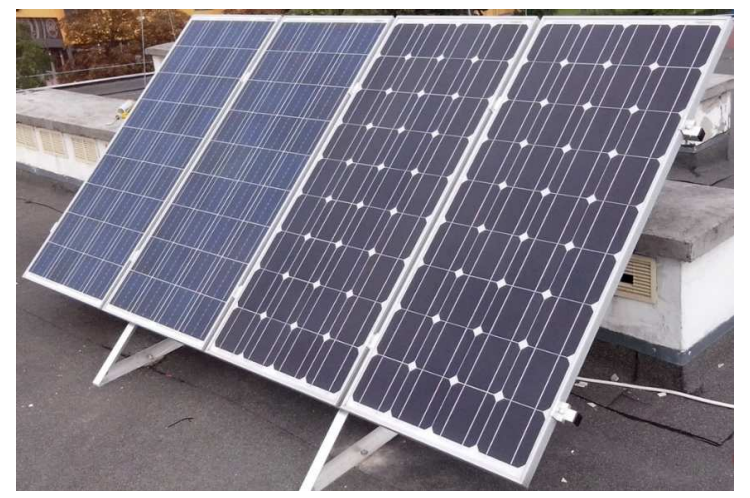

Fig. 1. Photovoltaic PV generator: left side polycrystalline PV modules - CL-130-12 model, and right side PV monocrystalline modules -AEMF 130 model

The PV system uses inverters in the form of two Sunny Boy 240 micro inverters, which were connected to mono- and polycrystalline modules directly with the PV modules. An important element of the PV system is the Sunny Multigate device, which connects the PV mini system with the building's electrical network (connection to one phase) and the computer network router connected to the Internet. Fig. 2 presents a simplified wiring diagram of all elements of the PV system.

A maximum of 12 Sunny Boy 240 micro inverters can be connected to one Sunny Multigate network interface device. In order for the PV installation data to be sent to the Sunny Portal server, it is necessary to register the installation based on individual device numbers assigned by the manufacturer. After a properly carried out registration process, the system every 15 minutes sends data to the server separately for each micro inverter. There is also the possibility of local monitoring using the Sunny Explorer application, if the location of the system does not allow connection to the Internet. Fig. 3 presents a functional diagram of the PV system and ways registering of energy yields.

The maximum output power of Sunny Boy 240 micro inverters is $245 \mathrm{~W}$. PV modules with a total peak power of $260 \mathrm{~W}_{\mathrm{p}}$ were connected to each of them. This configuration is correct, because for the analysed geographical location the maximum allowable nominal power factor is NPR=1.2 (Nominal Power Ratio), and we define it as a ratio of peak power 
of the PV generator to the maximum power of the inverter. The NPR coefficient calculated according to the above definition is equal 1.06, which is acceptable due to the lack of real possibilities of obtaining peak power by the PV panel (see in Fig. 9). Such a load on the PV inverter would be wrong in the inter-tropic geographic zone, where the PV generator may even exceed its peak power value due to the higher than the nominal solar radiation intensity occurring in these areas.

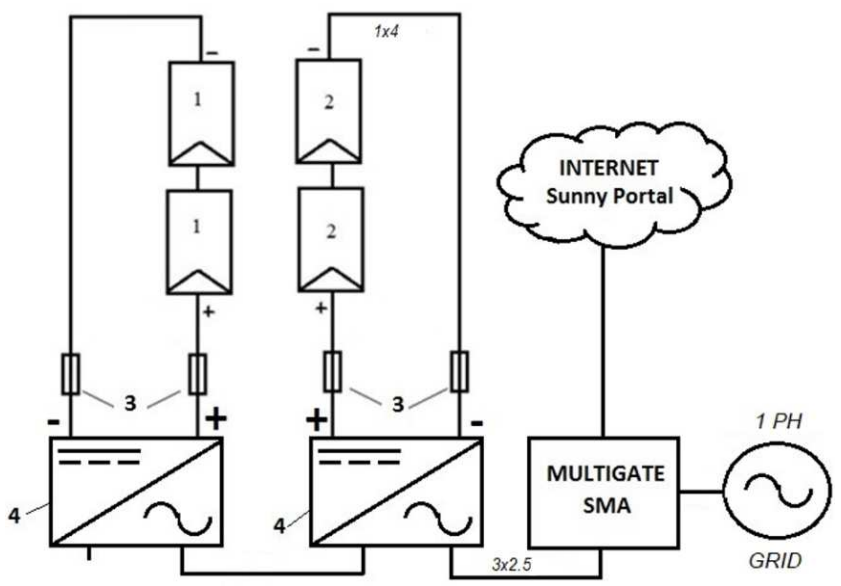

Fig. 2. Connection diagram for PV system components: 1-mono PV modules (AEMF130), 2-polycrystalline PV modules (CL130-12), 3-fuses, 4-micro inverters Sunny Boy 240

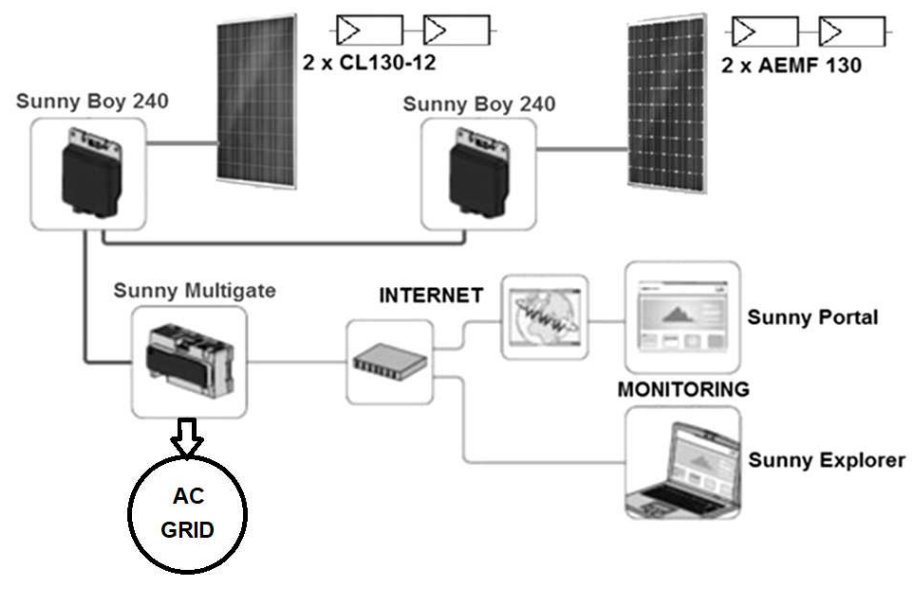

Fig. 3. Functional scheme of the PV mini system

\section{Research methodology}

No radiation measurements are made at the PV installation site. As comparative data was generated average monthly electricity production from the given system for four databases in PVGIS $[2,3]$. On this basis, it was estimated average monthly expected energy yield of PV system (Tab. 1).

The data obtained from the demonstration PV system in the years 2015-2017 were used for the analysis. The data was balanced on an annual basis and divided into individual months. The list was made for the whole system together and divided into outputs from 
mono- and polycrystalline PV modules. Analyzed values of energy yields are output data, energy coming from the micro inverters.

During the whole period of data collecting, the PV generator was not subjected to any operations. The results for 2017 are therefore subject to losses resulting from the accumulation of PV generator pollution. This is an important aspect because Płock is the seat of Poland's largest producer of liquid fuels, which affects significant air pollution. Near the PV generator, there is no position for measuring and recording the intensity of solar radiation and temperature.

Table 1. Average monthly electricity production from the given system (values for four databases in $\mathrm{kWh}$ ) [2,3] and average expected energy yield in $\mathrm{kWh} / \mathrm{kW}_{\mathrm{p}}$

\begin{tabular}{|c|c|c|c|c|c|}
\hline Month & $\begin{array}{c}\text { PVGIS- } \\
\text { CMSAF }\end{array}$ & $\begin{array}{c}\text { PVGIS- } \\
\text { SARAH }\end{array}$ & $\begin{array}{c}\text { PVGIS- } \\
\text { ERA5 }\end{array}$ & $\begin{array}{c}\text { Average } \\
\text { COSMO } \\
\text { expected } \\
\text { energy yield } \\
\text { of PV } \\
\text { yystem }\end{array}$ \\
\hline January & 14.4 & 16.2 & 17.8 & 13.6 & 29.8 \\
\hline February & 25.3 & 21.9 & 31.1 & 23.0 & 48.7 \\
\hline March & 49.4 & 42.5 & 54.0 & 44.2 & 91.4 \\
\hline April & 65.4 & 61.2 & 64.5 & 55.4 & 118.5 \\
\hline May & 68.9 & 65.6 & 64.8 & 57.6 & 123.5 \\
\hline June & 67.7 & 64.2 & 65.2 & 57.8 & 122.5 \\
\hline July & 67.4 & 64.7 & 63.5 & 55.2 & 120.6 \\
\hline August & 65.4 & 60.9 & 63.2 & 51.1 & 115.7 \\
\hline September & 53.5 & 52.8 & 51.0 & 42.9 & 96.3 \\
\hline October & 35.9 & 37.1 & 38.0 & 30.1 & 67.8 \\
\hline November & 16.8 & 16.7 & 18.2 & 13.5 & 31.3 \\
\hline $\begin{array}{c}\text { December } \\
\text { Annual sums } \\
\text { of energy } \\
\text { produced }\end{array}$ & 12.5 & 13.8 & 14.9 & 9.57 & 24.4 \\
\hline
\end{tabular}

\section{PV system tests results}

Figures 4-6 show the relative energy yields for subsystems with PV modules from mono- and polycrystalline silicon for each year, broken down by months. A thorough analysis of the measurement results shows a large difference in the generated energy between summer months: from April to September and winter months from October to March. The percentage distribution of generated energy and average values from three years are presented in Table 2.

Table 2. Percentage share of individual technologies in generating electricity

\begin{tabular}{|c|c|c|c|c|c|c|c|c|}
\hline $\begin{array}{c}\text { Generator } \\
\text { type }\end{array}$ & $\begin{array}{c}\text { Winter } \\
2015\end{array}$ & $\begin{array}{c}\text { Summer } \\
2015\end{array}$ & $\begin{array}{c}\text { Winter } \\
2016\end{array}$ & $\begin{array}{c}\text { Summer } \\
2017\end{array}$ & $\begin{array}{c}\text { Winter } \\
2017\end{array}$ & $\begin{array}{c}\text { Summer } \\
2017\end{array}$ & $\begin{array}{c}\text { Winter } \\
\text { average }\end{array}$ & $\begin{array}{c}\text { Summer } \\
\text { average }\end{array}$ \\
\hline $\begin{array}{c}\text { Poly- } \\
\text { crystalline }\end{array}$ & $25 \%$ & $75 \%$ & $23.5 \%$ & $76.5 \%$ & $24.2 \%$ & $75.8 \%$ & $24.2 \%$ & $75.4 \%$ \\
\hline $\begin{array}{c}\text { Mono- } \\
\text { crystalline }\end{array}$ & $10.9 \%$ & $89.1 \%$ & $10.6 \%$ & $89.4 \%$ & $14.6 \%$ & $85.4 \%$ & $12.0 \%$ & $88.0 \%$ \\
\hline
\end{tabular}




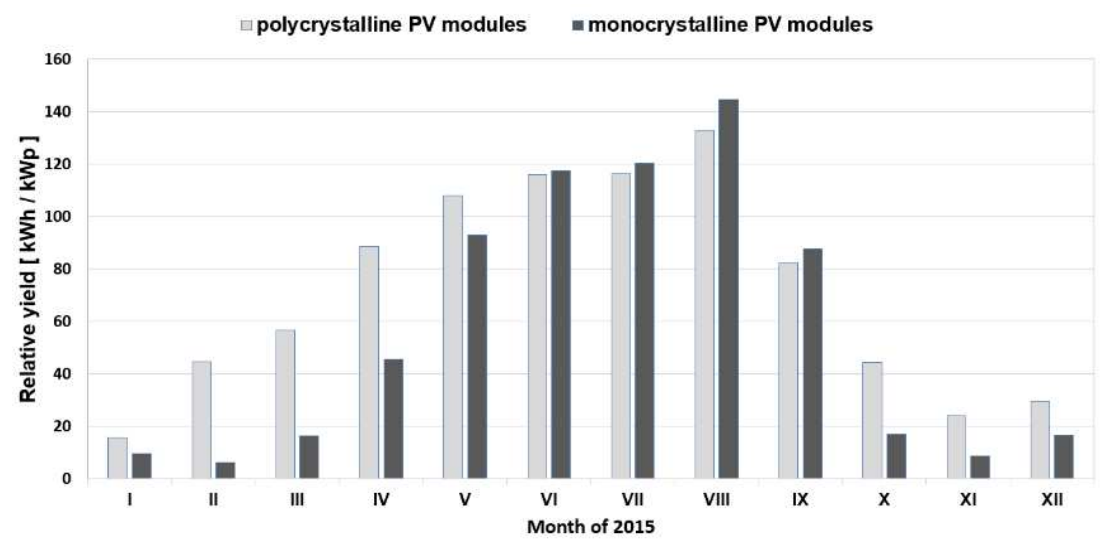

Fig. 4. Relative energy yields from the demonstrative PV system with division into months and generator manufacturing technologies in 2015

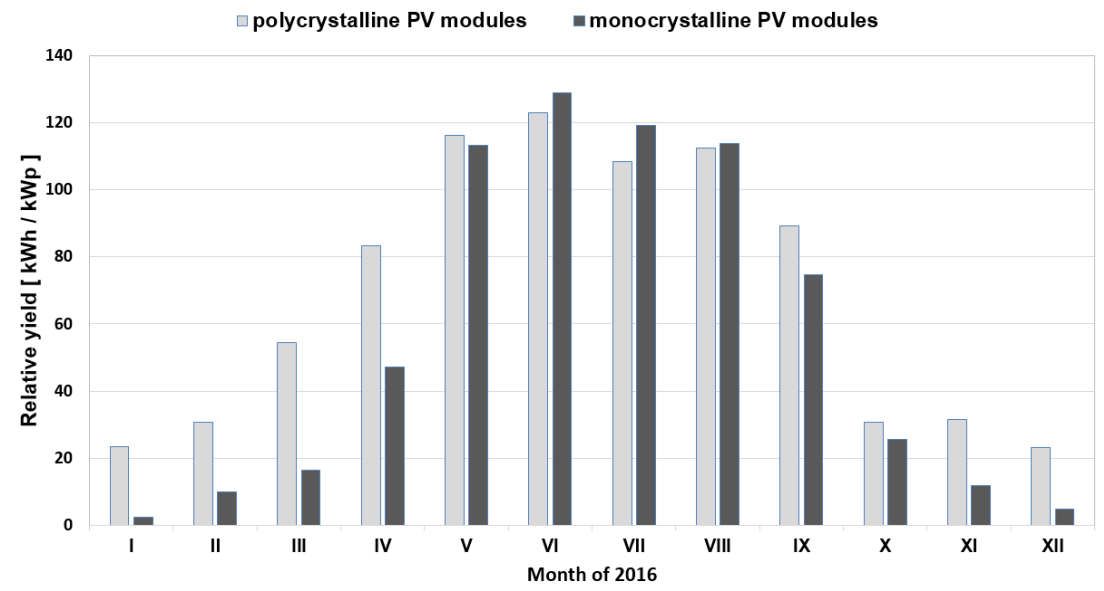

Fig. 5. Relative energy yields from the demonstrative PV system with division into months and generator manufacturing technologies in 2016

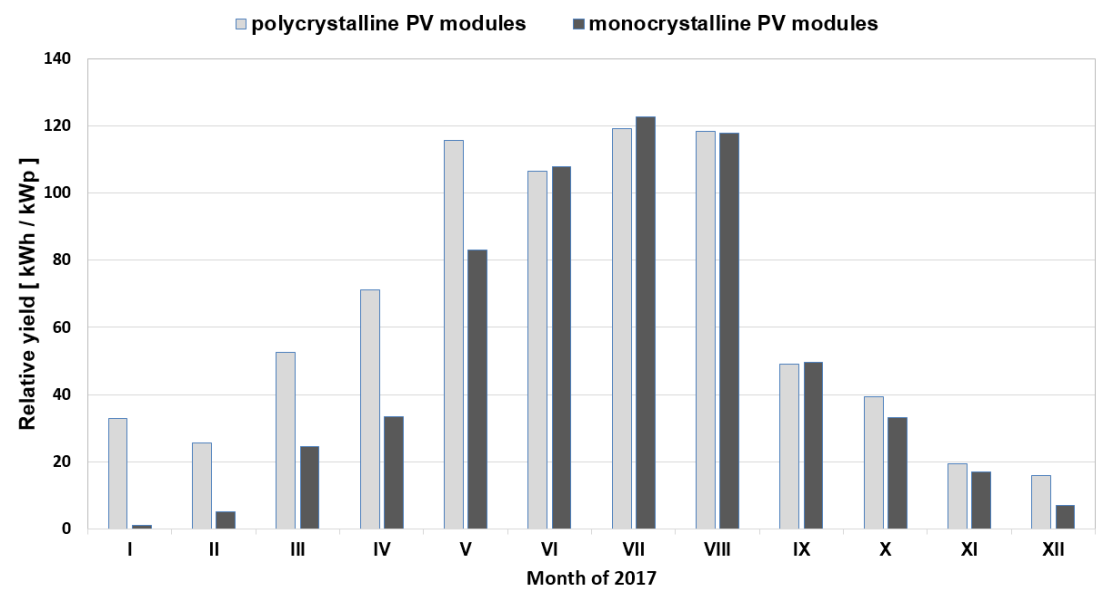

Fig. 6. Relative energy yields from the demonstrative PV system with division into months and generator manufacturing technologies in 2017 
Figure 8 show balances for the entire PV system in total. The listings were made in the same way as before, but without a division into the technologies of the PV generator. Figure 7 shows the part of the balance relating to the summer months, which in this case accounts for over $80 \%$ of the relative energy yield for the PV generator in 2015-2017.

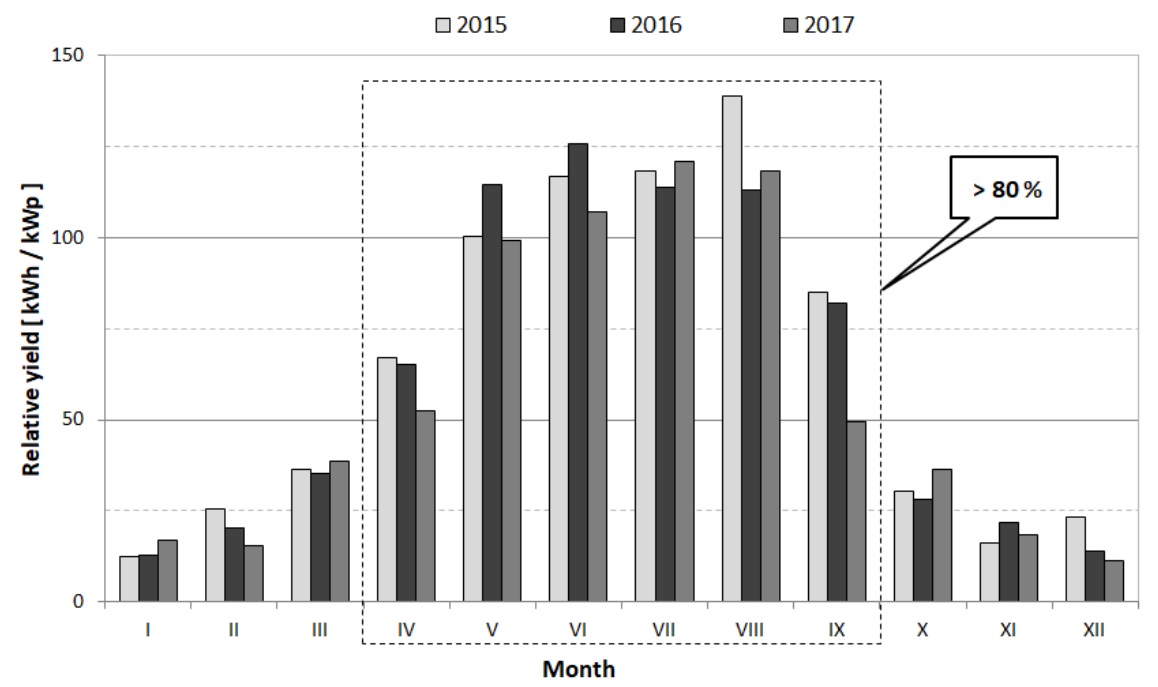

Fig. 7. Total balance of PV generator yields divided into months in 2015-2017

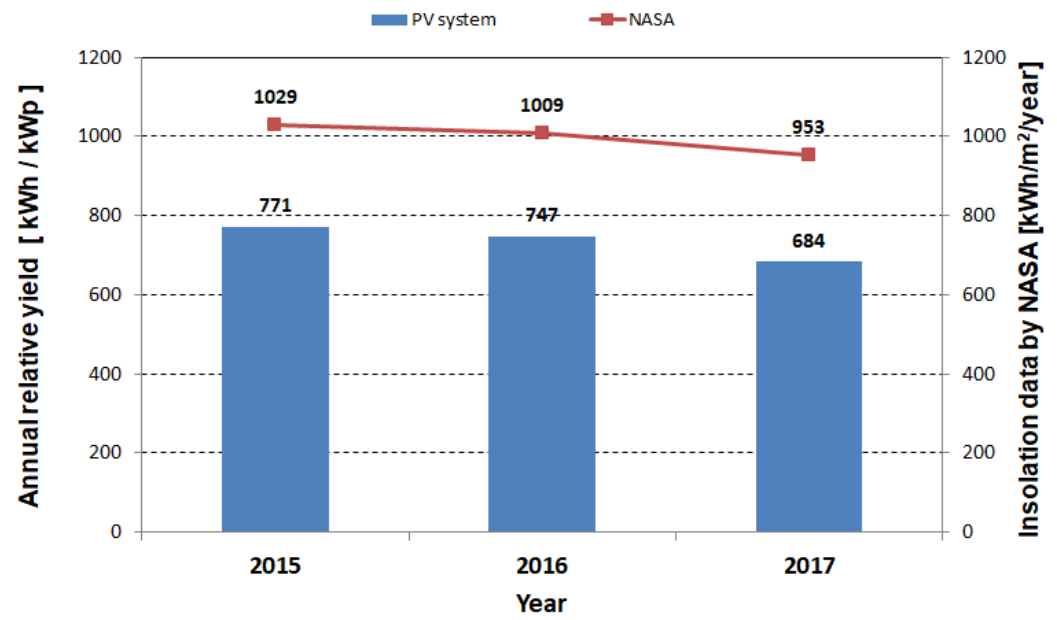

Fig. 8. The total balance of PV generator yields divided into years and insolation data by NASA [4]

Figure 9 shows the micro inverters power histogram for two selected days, characterized by the highest power values. This analysis show the real load of inverters throughout the considered period. This confirms the correctness of the PV generator selection for micro inverters at the NPR=1.06 level. Micro inverters did not work at maximum power in any time interval.

Figure 10 presents micro inverters power diagrams for an example of a "Winter Day" (2015-12-24) with the shading effect of a PV generator. The time of occurrence of the shading effect coincides with the direction of the location of two tall trees relative to the PV installation. 


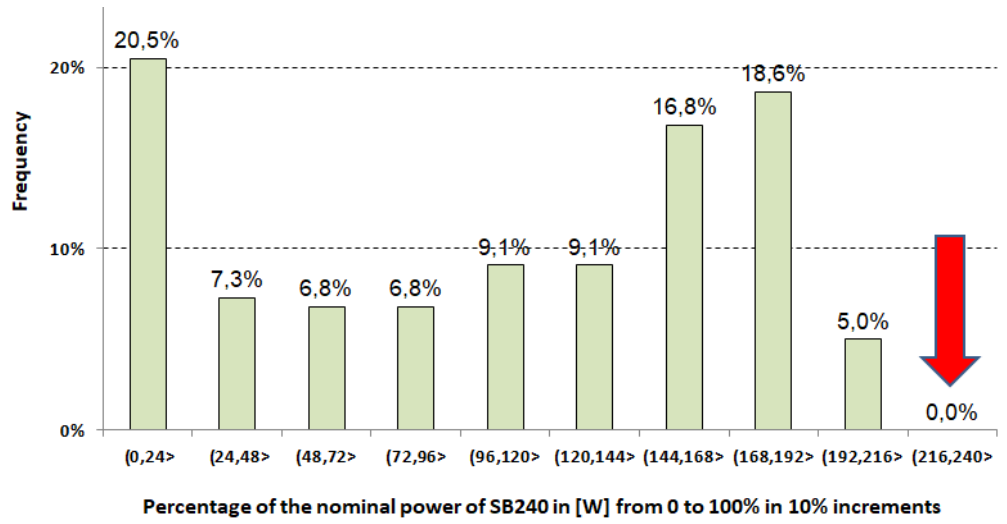

Fig. 9. Histogram of power distribution of micro inverters for two selected days: 2015-08-10 and 2015-08-11

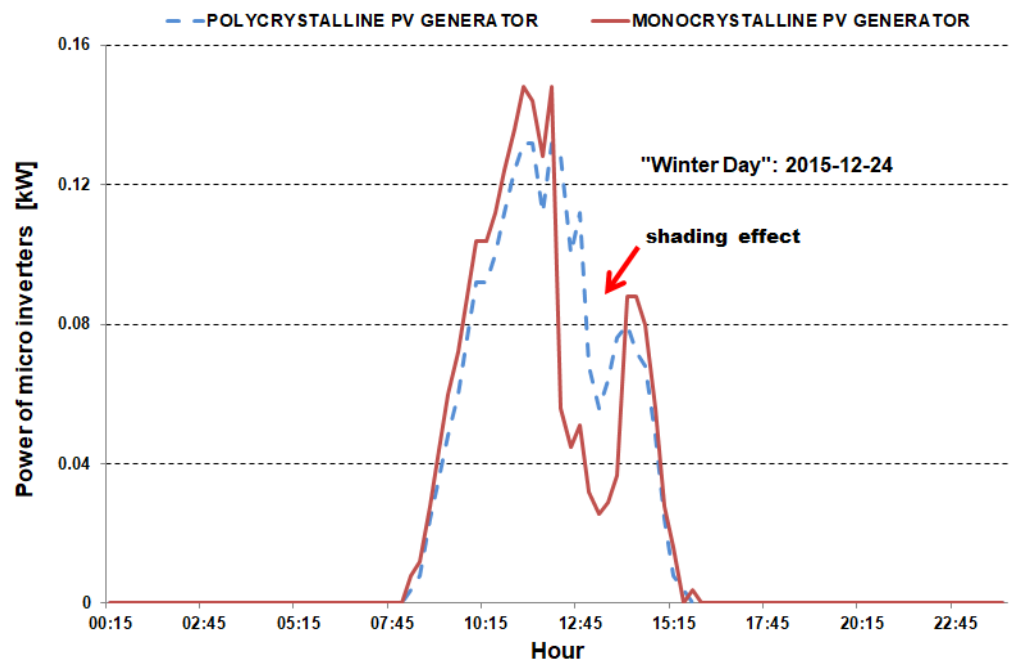

Fig. 10. Daily diagrams of power for micro inverters with an exemplary shading effect for the "Winter Day"

\section{Conclusion}

The analysis of energy yields for the described installation leads to the following conclusions:

- During the period of testing of the PV installation in 2015-2017, large differences in the annual values of generated electricity were observed (Fig. 8). In the summer months, i.e. from April to September, it was over 80\% (Tab. 2, Fig. 7).

- For the considered location, energy yields from the PV system in the given location were smaller than theoretically estimated (Tab. 1) and were characterized by a clear downward trend (Fig. 8). The relative decrease in solar insolation (calculated on year to year basis) shown Figure 8 is respectively: $1.98 \%$ and $5.58 \%$. The decrease in electricity produced (calculated in the same way) is $3.1 \%$ and $8.43 \%$. This clearly indicates the impact of a other factor (temperature, soiling or shadingof PV module). It is also 
recommended to install sensors for measurement of insolation and temperature at the PV installation location [5].

- One of the reasons for the lower generation of normalized energy is the shading effect visible in Fig. 10, which reduces the power of the generator made of monocrystalline PV modules. The exact of the shading effect on the PV generator's efficiency can be estimated on the basis of the 3D model of the shading elements relative to the location of the PV installation (e.g. in the PVSYST software) [6-8].

- Another recommendation resulting from the analysis of experimental results is to examine the influence of the of the tilt angle of PV panels on the degree of selfcleaning, while maintaining the criterion of maximizing energy yields, similar suggestions can be found in the literature, e.g. $[9,10]$.

- The long time consumed by the research presented in the work (three-year observations) prompts to conduct such analyzes in a simulation manner on models. In the Matlab / SImulink package, two dedicated components were implemented: "Solar Cell" and "PV Array", which can be used to build a PV generator model [11-15].

\section{References}

1. Pietruszko S. Photovoltaic market in Poland - 2017, Magazyn Fotowoltaika, 1, pp. 6-11, (1018)

2. Photovoltaic Geographical Information System (PVGIS 5 beta release) http://re.jrc.ec.europa.eu/pvg_tools/en/tools.html\#PVP

3. Huld, R. Muller, Gambardella A., A new solar radiation database for estimating PV performance in Europe and Africa, Solar Energy, 86, 6, pp. 1803-1815, (2012)

4. RETScreen - Clean Energy Management Software system for energy efficiency, renewable energy and cogeneration project feasibility analysis as well as ongoing energy performance analysis http://www.nrcan.gc.ca/energy/software-tools/7465

5. Rodziewicz T., Teneta J., Zaremba A., et al. Cheap Sensor Made of Multicrystalline Silicon for Insolation and Temperature Measurements, Ecological Chemistry and Engineering, 23, 4, pp. 583-591, (2016)

6. Goss B., Cole I., Betts T., Gottschalg R. Irradiance modelling for individual cells of shaded solar photovoltaic arrays, Solar Energy, 110, pp. 410-419, (2014)

7. Lua F., Guoa S., Walsha T.M.,Aberlea A.G. Improved PV Module Performance Under Partial Shading Conditions, Energy Procedia, 33, pp. 248-255, (2013)

8. Fialhoa L. Melicioa R., Mendesa V.M.F., Figueiredoa J., Collares-Pereiraa M. Effect of Shading on Series Solar Modules: Simulation and Experimental Results, Procedia Technology, 17, pp. 295-302, (2014)

9. Styszko K., Jaszczur M., Teneta J., et al., An analysis of the dust deposition on solar photovoltaic modules, Environmental Science and Pollution Research, (2018)

10. Jaszczur M., Teneta J., Styszko, Hassan Q., Burzyńska P., Marcinek E., Łopian N. The field experiments and model of the natural dust deposition effects on photovoltaic module efficiency, Environmental Science and Pollution Research, (2018)

11. Messenger R.A., Ventre J., Photovoltaic Systems Engineering Third Edition, CRC Press Taylor \& Francis Group, (2010)

12. Sarniak M., Budowa i eksploatacja systemów fotowoltaicznych, Wydawnictwo Grupa Medium, Warszawa, (2015)

13. Sarniak M. Modeling of photovoltaic modules in Simulink and Simscape packages of Matlab software. Econtechmod. An International Quarterly Journal, 6, 1, pp. 133-138, (2017) 
14. Khatib T., Elmenreich W., Modeling of Photovoltaic Systems Using MATLAB: Simplified Green Codes, John Wiley \& Sons, (2016)

15. Venkateswarlu G., Sangameswar Raju P.S. Simscape Model of Photovoltaic Cell, International Journal of Advanced Research in Electrical, Electronics and Instrumentation Engineering, 2, 5, pp. 2320-3765, (2013) 